\title{
Disease Response Elapsed Time
}

National Cancer Institute

\section{Source}

National Cancer Institute. Disease Response Elapsed Time. NCI Thesaurus. Code C162129.

The interval between two disease response reference time points. 